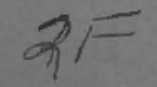

\title{
Accelerated Aging Tests of Liners for Uranium Mill Tailings Disposal
}

\author{
S. M. Barnes \\ J. L. Buelt \\ V. Q. Hale
}

November 1981

Prepared for the U.S. Department of Energy under Contract DE-AC06-76RLO 1830

Pacific Northwest Laboratory Operated for the U.S. Department of Energy by Battelle Memorial Institute 


\title{
NOTICE
}

This report was prepared as an account of work sponsored by the United States Government. Neither the United States nor the Department of Energy, nor any of their employees, nor any of their contractors, subcontractors, or their employees, makes any warranty. express or implied, or assumes any legal liability or responsibility for the accuracy. completeness or usefulness of any information, apparatus, product or process disclosed, or represents that its use would not infringe privately owned rights.

The views. opinions and conclusions contained in this report are those of the contractor and do not necessarily represent those of the United States Government or the United States Department of Energy.

\author{
PACIFIC NORTHWEST LABORATORY \\ operated by \\ BATTELLE \\ for the \\ UNITED STATES DEPARTMENT OF ENERGY \\ Under Contract DE-AC06-76RLO 1830
}
Printed in the United States of America
Available from
National Technical Information Service
United States Department of Commerce
5285 Port Royal Road
Springfield. Virginia 22151

Price: Printed Copy $\$$

$\because$ Microfiche $\$ 3.00$

NTis
-Pages Selling Price

\begin{tabular}{|r|r|}
\hline $001-025$ & $\$ 4.00$ \\
$026-050$ & $\$ 4.50$ \\
$051-075$ & $\$ 5.25$ \\
$076-100$ & $\$ 6.00$ \\
$101-125$ & $\$ 6.50$ \\
$126-150$ & $\$ 7.25$ \\
$151-175$ & $\$ 8.00$ \\
$176-200$ & $\$ 9.00$ \\
$201-225$ & $\$ 9.25$ \\
$226-250$ & $\$ 9.50$ \\
$251-275$ & $\$ 10.75$ \\
$276-300$ & $\$ 11.00$ \\
&
\end{tabular}


DOE UMMT-0205

PNL-4049

UC-70

ACCELERATED AGING TESTS OF LINERS FOR URANIUM MILL TAILINGS DISPOSAL

S. M. Barnes

J. L. Buelt

V. Q. Hale

November 1981

Prepared for the U.S. Department of Energy under Contract DE-AC06-76RLO 1830

Pacific Northwest Laboratory

Richland, Washington 99352 


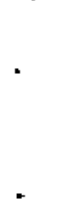

' 


\section{SUMMARY}

This document describes the results of accelerated aging tests to determine the long-term effectiveness of selected impoundment liner materials in a uranium mill tailings environment.

The study was sponsored by the U.S. Department of Energy under the Uranium Mill Tailings Remedial Action Project. The study was designed to evaluate the need for, and the performance of, several candidate liners for isolating mill tailings leachate in conformance with proposed Environmental Protection Agency and Nuclear Regulatory Commission requirements.

The liners were subjected to conditions known to accelerate the degradation mechanisms of the various liners. Also, a test environment was maintained that modeled the expected conditions at a mill tailings impoundment, including ground subsidence and the weight loading of tailings on the liners. A comparison of installation costs was also performed for the candidate liners.

The laboratory testing and cost information prompted the selection of a catalytic airblown asphalt membrane and a sodium bentonite-amended soit for fiscal year 1981 field testing. 


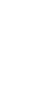

- 


\section{CONTENTS}

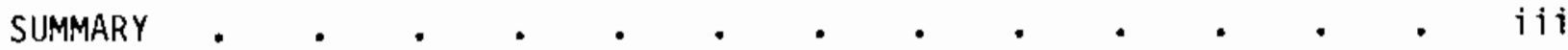

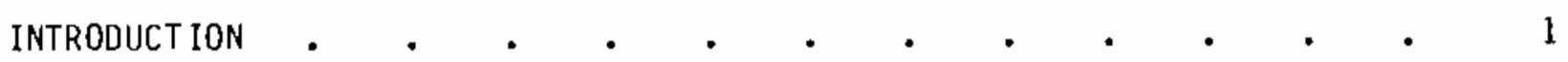

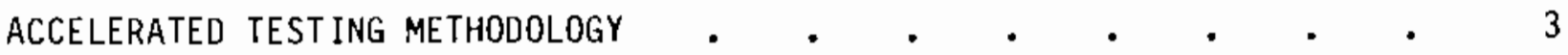

OXIDATION OF ASPHALTS AND SYNTHETICS $\quad \cdot \quad \cdot \quad \cdot \quad \cdot \quad \cdot \quad \cdot \quad \cdot 3$

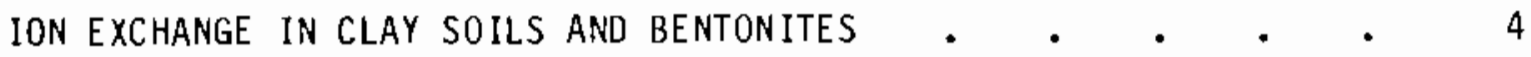

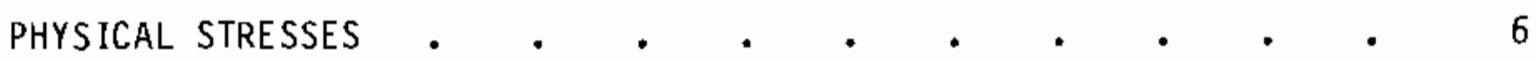

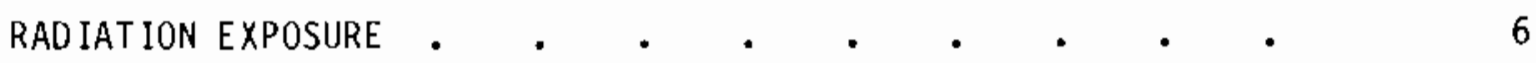

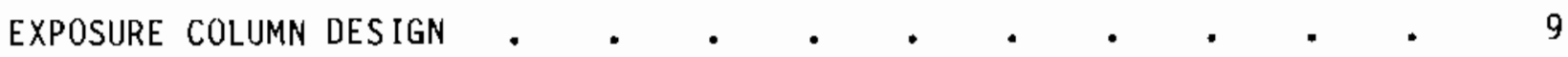

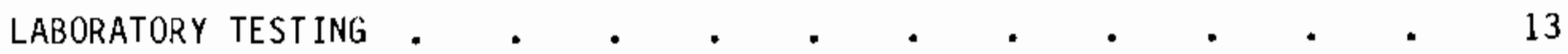

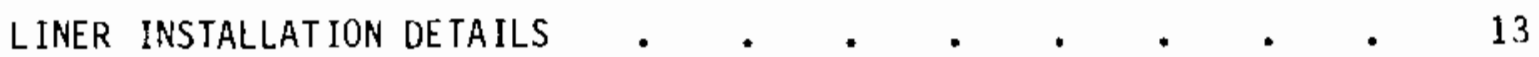

Asphalt Concrete Liner . . . . . . . . 13

Catalytic Airblown Asphalt Liner . . . . . . 14

Asphait-Rubber Liner $\quad$. . . . . . . . . 14

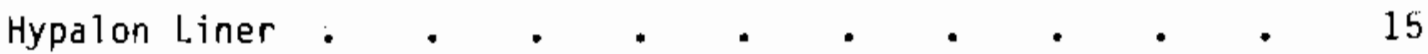

Sodium Bentonite Liner . . . . . . . . . 15

Saline Seal 100 and GSR-60 Liners . . . . . . 15

Native Soil Liner . • . • • • • . . . 15

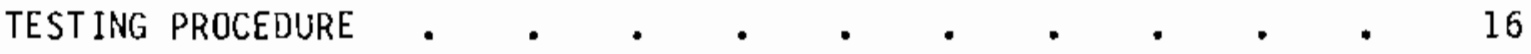

LABORATORY TEST RESULTS

Asphalt and Synthetic Liners . . . . . . . 19

Clay Liners . . . . . . . . . . . . . . 24

LINER INSTALLATION COSTS •

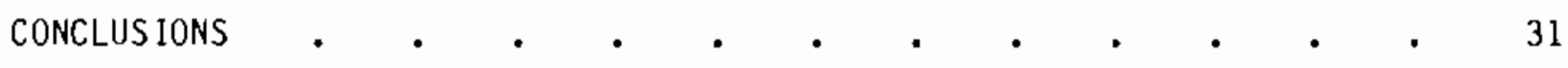




REFERENCES
APPENDIX A-ASPHALT LINER SPECIFICATIONS




\section{FIGURES}

1 Typical Disposal Site for Predicting Subsidence . $\quad$. $\quad$ e $\quad 6$

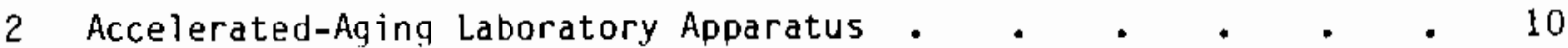

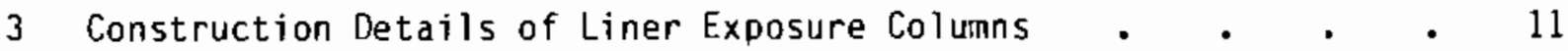

4 Permeability Performance of the Asphalt and Hypalon Liners During the Laboratory Testing Period . . . . . . . . . 18

5 Permeability Performance of the Clay-Amended and Natural Soil

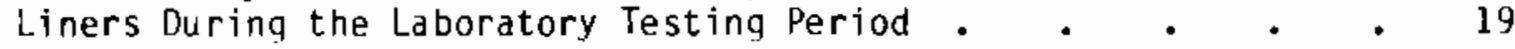

6 0xygen Pressure to Which Asphalt and Synthetic Liners were Exposed During Testing . • • • • • • . • . 21

7 Exposure Temperature of Asphalt and Synthetic Liners During Testing 22

8 Acidity Concentration During Testing of Asphalt and Synthetic

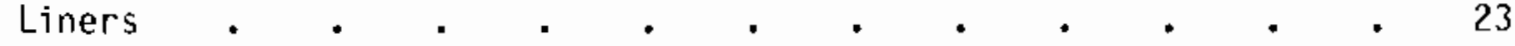

9 Pressure History During Testing of Clay Liners . . . . . . 26

10 Acidity Concentration During Testing of Clay Liners * * * 27

\section{TABLES}

1 Anticipated Field Liner Permeabilities . . . . . . . 20

2 Installation Costs of the Candidate Liner Materjals . • • 29

A.l AR4000 Asphalt Cement Specifications . . . . . . . . A.1

A.2 Hydraulic Asphalt Concrete Aggregate Specifications - * . A.1

A.3 Catalytic Airblown Asphalt Specifications . . . . . . B.2

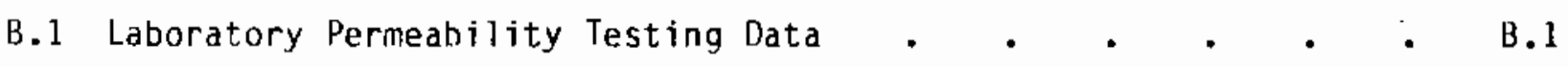



INTRODUCT ION

The U.S. Department of Energy (DOE) has created the Uranium Mill Tailings Remedial Action (UMTRA) Project for final disposition of 25 inactive uranium tailings sites, as required by Public Law 95-604. Under the technology development task of this program, Pacific Northwest Laboratory (PNL) is performing a study to determine the technological requirements for preventing the migration of hazardous chemicals and radionuclides from some of these selected sites. The objective of the study is to evaluate the need for and long-term effectiveness of various liner materials in conformance with proposed Environmental Protection Agency (EPA) criteria and Nuclear Regulatory Commission (NRC) licensing requirements.

To accomplish this objective, PNL has completed the first phase of accelerated-aging tests in the laboratory. Eight liner materials were selected for accelerated-aging testing based on a literature and industrial survey described in a previous status report (Buelt, Hale, Barnes, and Silviera 1981). The materials were selected on the basis of currently available information on the effectiveness of the materials when in prolonged contact with leachate similar to that of uranium mill tailings. The selected materials are:

- hydraulic asphalt concrete

- catalytic airblown asphalt membrane

- rubberized asphalt membrane

- chlorosulfanated polyethylene (hypalon)

- natural soil from a typical disposal site

- soil amended with sodium bentonite

- soil amended with Saline Seal 100\%

- soil amended with GSR-60®.

The clay liner materials listed above (Saline Seal 100, GSR 60) differ slightly from those listed in the status report. This change permitted a

@Registered trademark of American Collojd Co., Skokie, Illinois. Registered trademark of American Colloid Co., Skokie, Illinois. 
broader evaluation of sodium bentonite-based liner materials. Also, cover materials proposed for radon attenuation were not evaluated as an impoundment water barrier. This allowed each liner to be evaluated independently without the possible permeability interference that could arise from the cover materials.

The eight liner materials were placed in 0.6-m-dia exposure columns and subjected to conditions that would accelerate the aging process. The performance of each material was evaluated by comparing the changes in permeability with time of exposure. The two most suitable liners were then selected for further evaluation by exposing them to real-time conditions in the field. This current study describes the accelerated-aging methodology and results of the laboratory tests.

The intention of this study was to select the best liner(s) listed above for further evaluations in the field. The selection was based on the conformance to presently proposed EPA criteria. These criteria state that when it is necessary to relocate a tailings pile to a new site, the disposal site must be designed such that the ground water $100 \mathrm{~m}$ away from the site not exceed maximum permissible concentrations of certain radionuclides and hazardous compounds for $1000 \mathrm{yr}$ (EPA 1981). At this time, the liner permeability data collected in this study cannot be directly related to conformance of these proposed criteria. Continuing investigations are developing the technology required to determine the need for and type of lining (e.g., leachate barrier, chemical filter, etc.) as required at a disposal site by the proposed EPA criteria. For the purposes of the study presented in this report, the selection of liners for field testing was based on their long-term performance as leachate barriers. 


\section{ACCELERATED TEST ING METHODOLDGY}

Since proposed EPA regulations require that the mill tailings disposal sites conform for 1000 yr to EPA criteria, it was felt that the best way to determine the long-term liner effectiveness was to accelerate the aging mechanisms of each liner while maintaining conditions as nearly representative of the field as possible. It was equally as important to select the destructive mechanisms which would be realized in the field. For example, ultraviolet degradation of the asphalts was not considered as the liner would be covered for all of its useful life. Likewise, freeze/thaw and wet/dry cycles were eliminated from practical consideration since a thick cover of tailings and soil over the liners will eliminate the possibility of such extremes.

The behavior of clay amendments and asphalt and synthetic liners are such that different accelerated testing methodologies had to be employed. Asphalt and synthetic materials degrade primarily by oxidation, which causes the materials to become hard and brittle. The most serious degradation mechanism for clay materials is the ion-exchange reaction between sodium present in the clays and calcium, which exists in high concentrations in uranium tailings leachates. This ion-exchange reaction reduces the swelling capabilities of the clay, thus increasing leachate permeability. Both asphalt and clay materials, however, are subjected to the same physical stresses caused by ground subsidence when the tailings are introduced to the disposal site. Gamma radiation effects over the 1000-yr period were also considered for both classifications of materials.

OXIDATION OF ASPHALTS AND SYNTHETICS

Two types of oxidation reactions occur with asphalts. The first, known as auto-oxidation, is caused by the diffusion of oxygen through the surface of the asphalt and subsequent reaction with the hydrocarbon. The second occurs when aqueous oxidizing agents, such as sulfates and chlorides, react with the asphalt surface. Both reactions cause hardening and embrittlement of the liner. 
The oxidation reaction rate of the asphaltic and synthetic materials can be increased by elevating the temperature, acidity, and oxygen concentration to which they are exposed. The quantitative effect of each of these parameters can be determined by reaction kinetics. Since time restraints prevented an empirical determination of the reaction kinetics, the liners were assumed to behave identically to pavement asphalts in the absence of light. Studies by Van Oort (1956) and Blokker and van Hoorn (1959) empirically determined the reaction kinetics for auto-oxidation of pavement asphalts, but they disagreed on the degree that oxygen and temperature accelerate the reaction rate. By exposing the liners to $0.68 \mathrm{~atm}$ of pure oxygen at $50^{\circ} \mathrm{C}$ for $3 \mathrm{mo}$, which is achievable in the exposure columns, the equivalent time exposure is $320 \mathrm{yr}$, according to Van 0ort's studies, but is $53 \mathrm{yr}$ on the basis of Blokker and van Hoorn's relationships. The actual equivalent time exposure for the liner materials has not been determined in these studies, but attempts to quantify the expected lifetime of the most suitable materials will be performed in future studies.

The oxidizing strength of aqueous oxidizing agents has been accelerated by elevating the temperature and increasing the acidity of the leachate from the lowest measured $\mathrm{pH}$ of 2.9. The hydrogen ion concentration for the following elementary half reaction

$$
\mathrm{SO}_{4}^{=}+4 \mathrm{H}^{+}+2 \mathrm{e}^{-} \longrightarrow \mathrm{SO}_{2}(\mathrm{~g})+2 \mathrm{H}_{2} \mathrm{O}
$$

affects the reaction rate by the relationship

$$
\text { reaction rate } \propto\left[\mathrm{H}^{+}\right]^{4} \text {. }
$$

Therefore, a slight increase in acidity will accelerate the aging process by a significant amount.

ION EXCHANGE IN CLAY SOILS AND BENTONITES

The swelling property of a clay depends upon its ability to nold hydrated sodium ions in its exchange complex. Aside from physical disruptions, the 
failure of a clay liner will result from a loss of its swelling property. It can be lost either through a cation-exchange reaction that replaces the sodium in the clay's exchange complex with divalent cations, such as calcium, or from the dehydrating effect of a high-salt solution that removes the water of hydration from the exchangeable sodium. Both of these effects are controlled by the concentration of salts in the contacting solution.

The reason that concentration affects the exchange reaction is that it is a mass-action phenomenon. In this testing program, it was necessary to provide the conditions conducive for the mass-action over a short period of time that might be obtained over the long term in an actual impoundment. To accelerate the ion-exchange reaction, a thin clay liner was used and pressurized air was introduced to the exposure columns to apply pressure to the leachate solution above the liner. In this manner, it was possible to measure the relationship of permeability with the number of pore volumes of tailings leachate that pass through the liner.

By equating the permeability and number of pore volumes in Darcy's equation for saturated flow (Hillel 1980), the exposure time in the laboratory can be related to equivalent time in the field by the relationship

$$
\frac{t_{1}}{t_{2}}=\frac{\left(z_{1} / z_{2}\right)^{2}}{p_{1} / p_{2}} \text {, }
$$

where $\mathrm{t}=$ time;

$\ell=1$ iner thickness;

$p=$ hydrostatic pressure;

1 = reference to laboratory measurements;

2 = reference to field measurements.

As the relationship shows, by exerting an increased hydrostatic pressure over a thin liner relative to that expected in the field, the liner aging can be accelerated. 


\section{PHYSICAL STRESSES}

When tailings are introduced to the disposal site, the soil mantle beneath the liner is expected to subside somewhat. This subsidence will cause elongation or shifting of the liner along the sloped walls of the disposal site.

Figure 1 is a model of a typical disposal site. From this model, anticipated subsidence was calculated to be $33 \mathrm{~cm}$. Assuming a $3: 1$ excavation slope with a tailings depth of $6 \mathrm{~m}$, the maximum elongation a liner must withstand is $0.035 \mathrm{~cm} / \mathrm{cm}$, or $3.5 \%$. This value was duplicated in the accelerated tests for both clay, and asphalt and synthetic liners.

\section{RADIAT ION EXPOSURE}

Gamma radiation exposure to the liners was estimated for a $1000-y r$ period by making certain assumptions and relationships. Assuming the relaxation

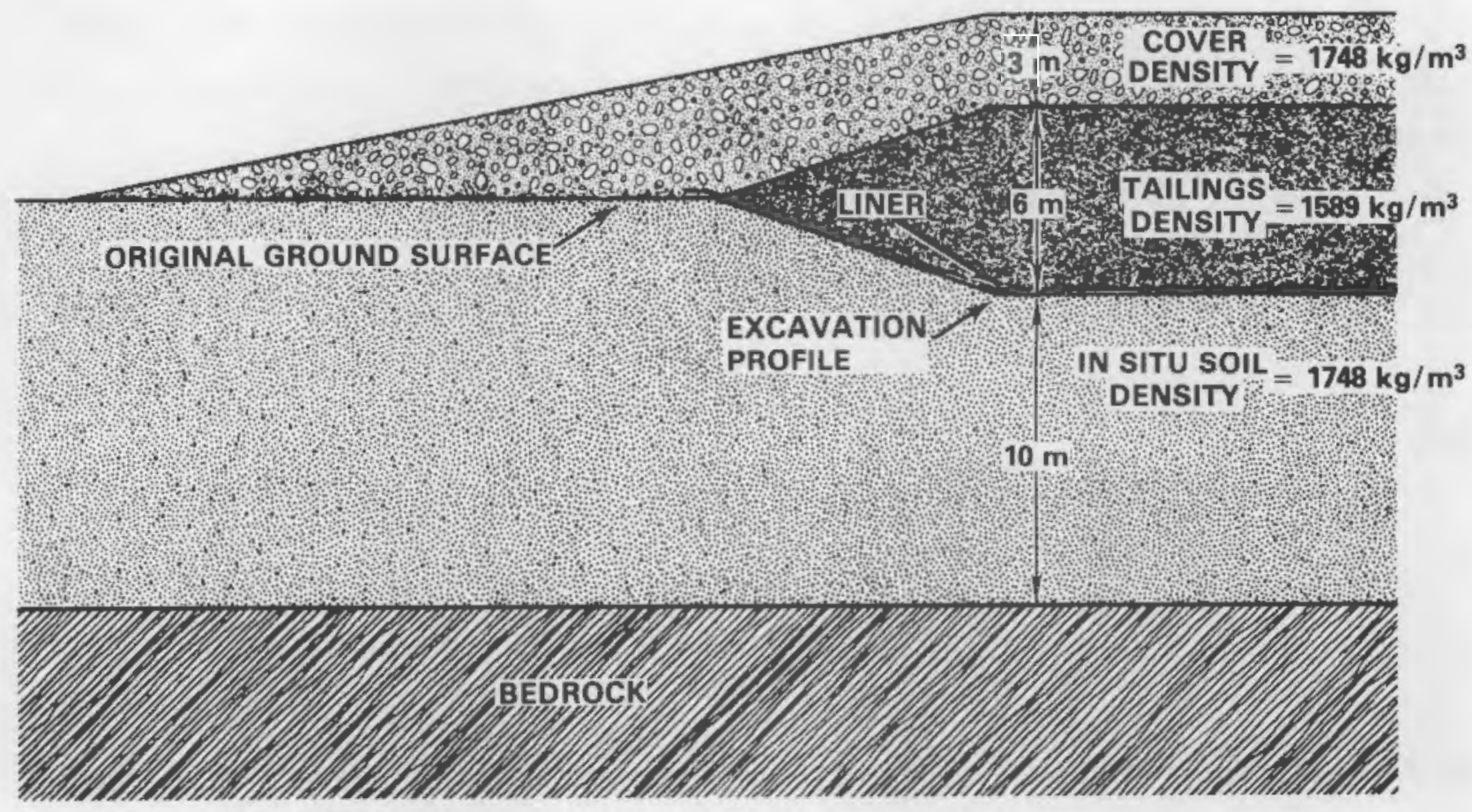

FIGURE 1. Typical Disposal Site for Predicting Subsidence 
length of tailings is the same as concrete $(6.5 \mathrm{~cm}$ at $0.35 \mathrm{MeV})$, a surface source was estimated for the tailings above the liner according to the relationship

$$
S=1 / 2 S V \lambda \text { (Foster and Wright 1973) }
$$

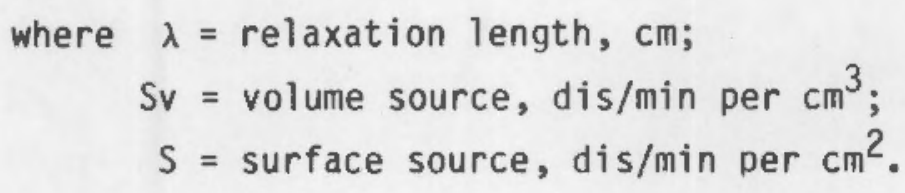

The volume source was estimated from the highest gamma activities detected from the Salt Lake City, Shiprock, and Durango tailings piles for the ${ }^{238} U$ decay chain. The volume source used in the exposure calculation was 36,000 dis/min per $\mathrm{cm}^{3}\left(16 \mathrm{nCi} / \mathrm{cm}^{3}\right)$, which is much higher than typically found in tailings. The absorbed energy from gamma radiation expected at this level incident to the liners over the $1000-y$ r period is $10^{4} \mathrm{R}$. A circular sample of each liner was irradiated from a point source of ${ }^{60} \mathrm{Co}$ at $10^{5} \mathrm{R}$ at the center. No effects were observed on the liner materials from this irradiation. 



\section{EXPOSURE COLUMN DESIGN}

Eight sealed columns were fabricated for liner testing to produce a controlled environment in which the liners were exposed to accelerated aging conditions. The liner exposure columns, shown in Figure 2, were constructed of 61-cm (24-in.) 304L stainless steel pipe. The columns were designed to simulate expected field conditions and to expose the candidate liners to the accelerated-aging mechanisms described earlier. The design features of the columns are depicted in Figure 3.

The characteristics of an impoundment that must be simulated in the exposure columns include the forces exerted by the tailings above the liner; the pressure head of tailings leachate in the impoundment, if any; and subsidence of the supporting substrate. The weight of the tailings above the liner was duplicated by applying a representative force on the simulated tailings in the column with the piston shown in Figure 3. The piston was fabricated with perforated plating to permit free flow of the simulated leachate while the desired load was applied to the sand. The head of tailings leachate above the liner was simulated by applying gas pressure to the test cylinder above the liner. The effects of ground subsidence were simulated by a collapsible, water-filled bladder installed in the supporting sand beneath the liner. The bladder was constructed from two hypalon sheets clamped at the edges with polyvinyl-chloride rings. The space between the hypalon sheets was filled with sufficient water to produce the displaced volume required to model the subsidence.

The bottom of each exposure column was sloped to direct the fluid passing through the liner to the drain. The welded bottoms of the column, constructed of carbon steel, were coated with an asphalt layer or an epoxy resin for corrosion protection.

The exposure columns that contained the asphalt and hypalon liners were heated by circulating hot water through external copper coils. The heating 


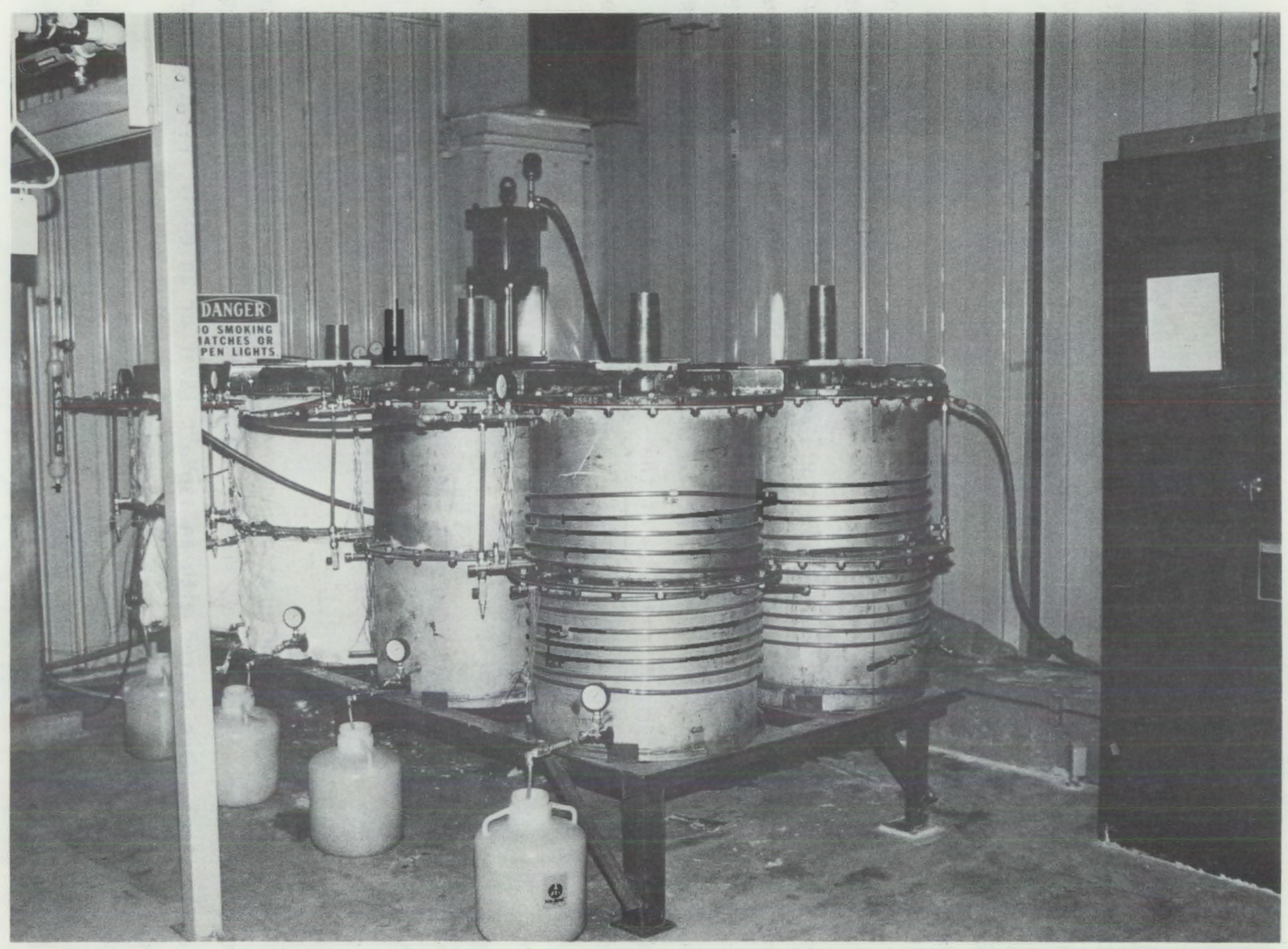

FIGURE 2. Accelerated-Aging Laboratory Apparatus 


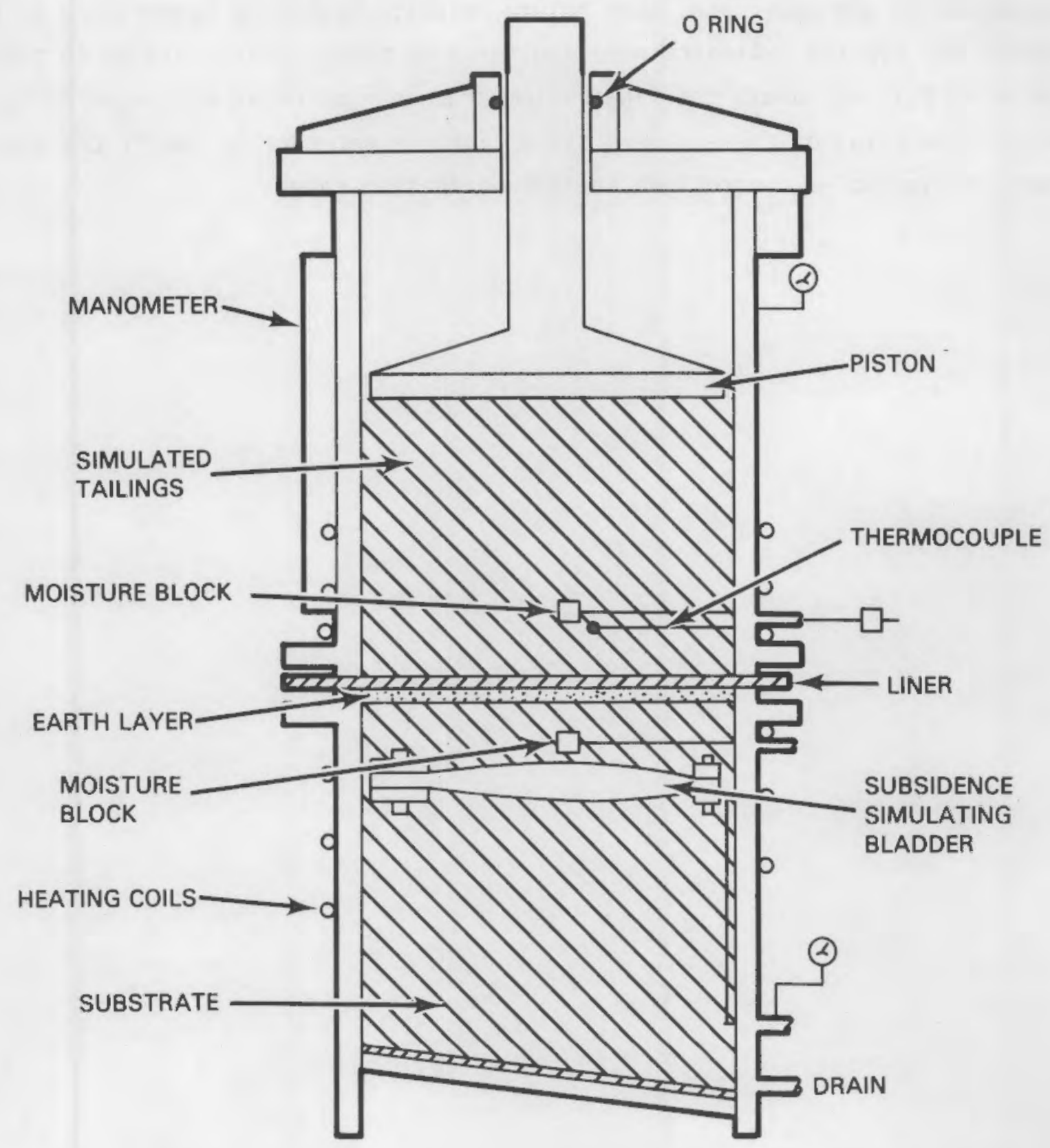

FIGURE 3. Construction Details of Liner Exposure Columns

coils were centered around the liner to provide uniform heating. The circulating water temperature was controlled by a heat pump/heating tape system.

The exposure columns were instrumented with moisture blocks above and below the liners. The moisture blocks were installed to monitor the degree of 
saturation of the upper and lower column halves. Also, the temperature of the asphalt and hypalon cylinders were monitored by thermocouples placed in the simulated tailings above the liner. Temperature monitoring was required to predict the aging of these liners since liner temperature is one of the most important variables controlling the auto-oxidation rate. 


\section{LABORATORY TESTING}

This section describes the installation procedure and specifications of each of the liners, the laboratory testing procedure, and the experimental results of the accelerated-aging portion of the liner evaluation program.

\section{LINER INSTALLATION DETAILS}

The 1 iners and supporting soil were sandwiched in the exposure columns between simulated tailings and a supporting sand layer. The tailings above the liner in each of the columns were simulated with Wedron washed silica sand, Size No. 70. This sand was selected because it resembled the particle size distribution of samples removed from the New Rifle tailings pile (see Figure 2, Hartley et al. 1980), and it would not affect the chemical reactions between the leachate and the liner. The same sand was also used beneath the liners to minimize absorption of leachate that passed through the liners. Just below the asphalt and hypalon liners, a $0.5-\mathrm{cm}$ layer of soil was installed to subject the bottom surface of the liner to realistic conditions. Also, in every case, the centerlines of the subsidence bladder and moisture blocks were placed $9.5 \mathrm{~cm}$ and $3.2 \mathrm{~cm}$ helow the liners, respectively. The sand beneath the liner was compacted with a vibrating rod in each of the cylinders. Asphalt Concrete Liner

The asphalt concrete liner was produced by installing two $4.5-c m-t h i c k$ lifts of the admixed asphalt above a cationic asphalt emulsion tack coat. The asphalt emulsion was also applied to the cylinder walls to bond the liner to the exposure cylinder. An AR4000 asphalt cement was used to fabricate this liner. The liner was mixed at a ratio of $10 \%$ asphalt, $90 \%$ aggregate. The specifications of the asphalt concrete and the aggregate gradation are provided in Appendix A.

The asphalt and aggregate were heated to $200^{\circ} \mathrm{C}$ and mixed in two $12.5-\mathrm{kg}$ batches. After the mixing process, the admixture was reheated to $200^{\circ} \mathrm{C}$ and installed in the exposure column. The individual lifts were poured into the 
cylinder, leveled and partially compacted by hand, and then compressed to 78 psig in a hydraulic press. This pressure was chosen since it represents the compactive force developed in a 90-blow Marshall compaction procedure and also represents the compressive action of a 5 -ton vibratory roller. The lower asphalt concrete lift was allowed to cool 30 min before the upper lift was installed.

Catalytic Airblown Asphalt Liner

The catalytic airblown asphalt (CAA) membrane, a hot-sprayed liner, was also applied in two lifts. The asphalt was placed in a heated reservoir pressurized with nitrogen. The nitrogen pressure forced the CAA through a manually operated spray gun. The first lift was sprayed directly on the soil layer, and the second application was sprayed from an opposing direction to assure complete coverage of the surface. The CAA application rate for the completed liner was $6.8 \mathrm{l} / \mathrm{m}^{2}$; the CAA was sprayed at a temperature of $205^{\circ} \mathrm{C}$. The specifications of this liner are listed in Appendix A.

Asphalt-Rubber Liner

The asphalt-rubber composition used in this study is currently being installed on the cooling-water lagoons at the Palo Verde Nuclear Power Station. The asphalt mixture contained roughly 79\% ASTM Type 1 Roofing Asphalt; $19 \%$ U.S. Rubber Reclaiming GP274 reclaimed tire rubber; and $2 \%$ high boiling-point asphalt extender oil. The liner was fabricated on a specially treated paper backing at the University of New Mexico's Engineering Research Institute (UNMERI) and shipped to PNL. The asphalt application rate for this liner was $5.4 \mathrm{\ell} / \mathrm{m}^{2}$, the minimum application recommended by the staff at UNMER I .

Following receipt of the liner, it was removed from the paper backing and installed in the cylinder above the thin soil layer. Although a tear in the liner center developed during the paper-removal process, it was repaired by heating the damaged area with a propane torch and allowing the asphalt mixture to fuse together. This operation is not anticipated to affect the performance evaluation. 
Hypalon Liner

A sheet of $1.5-\mathrm{mm}$ chlorosulphonated polyethylene (hypalon) was placed above the $0.5-\mathrm{cm}$ soil layer. The liner was sealed to the cylinder with silicone rubber cement.

Sodium Bentonite Liner

The natural sodium bentonite clay was mixed at a weight ratio of $1: 10$ with a soil sample removed from a prospective disposal site for the Durango Tailings Pile (Bodo Canyon, Site D). The soil-clay mixture was premixed, moistened, installed in a 2.5-cm layer, and manually compacted to the maximum density attainable. (The compaction process was hindered by the motion of the fluid in the subsidence bladder.) The liner-cylinder wall joint was sealed by a layer of pure sodium bentonite clay.

Sal ine Seal 100 and GSR-60 Liners

Saline Seal 100 and GSR-60 are bentonite materials supersaturated with sodium and treated with polymer to slow the $\mathrm{Na}^{+} / \mathrm{Ca}^{+}$ion-exchange reactions with leachate. The polymer is not expected to interfere with the coprecipitation of hazardous ions in the leachate. In fact, should the bentonite become calcium-saturated, the permeability of the clay liner might increase, adversely affecting the capability to adsorb Ra.

The installation procedure for the processed bentonite liners was similar to that of the natural sodium bentonite liner. The same clay/soil ratio and procedure to seal the liner edges were employed, but because of procedural error these liners were not premoistened before compaction. Native soils from the Bodo $E$ site and the Long Hollow East Durango sites were used for the Saline Seal 100 and GSR-60 liners, respectively.

Native Soil Liner

A control liner of soil removed from the Bodo $E$ site was installed in one of the exposure columns. This liner was also dry-compacted to a $2.5-\mathrm{cm}$ thickness and sealed to the column by using the sodium bentonite liner installation 
technique. The earth was passed through a $0.6 \mathrm{-cm}$ sieve to remove larger rocks, which could have produced anomalous effects on a thin liner. No subsidence bladder was installed in this cylinder.

\section{TESTING PROCEDURE}

The permeability value measured for the liners in weekly testing cycles was based on the volume of simulated tailings leachate that passed through the liner. The displaced fluid volume was measured by either collecting and measuring the fluid flowing from the bottom drain of the cylinder, or by measuring the change in fluid level above the liner by using the cylinder manometer. The fluid collection method was used for the liners with the larger permeabilities, the latter method for the smaller-permeability cylinders. Measuring the volume change by both methods on a single exposure column was not practical.

Two primary sources of experimental error were identified after the first two testing cycles. The first source of error was the tailings leachate that passed through the liner between permeability measurement cycles. This fluid would supersaturate the lower half of the exposure column, and would be collected along with the leachate that penetrated the liner during the subsequent cycle. This additional fluid would increase the measured permeability above the actual value, especially for the higher permeability liners. In the latter measurement cycles, the exposure columns were allowed to drain freely for 5 min before the beginning of each cycle to remove the supersaturation fluid.

The second source of experimental error was caused by insufficient leachate in the cylinders for the longer-term tests. Initially, $-5 \&$ of fluid above the tailings saturation level was maintained in the test cylinders to permit cross-checking of the fluid loss numbers. Without sufficient excess solution, however, the liner would become exposed to the pressurizing gas as the leachate permeated the liner. Gas permeability through the liners is higher than liquid permeability, and therefore, as the gas passed through the liner, it tended to desaturate the sand below the liner. In effect, this 
produced more fluid in the collection vessel than actually passed through the liner during the testing cycle. This concern was eliminated in later cycles by ensuring that sufficient tailings liquor was present above the liner to prevent gas permeation of the liner.

The typical testing cycle was initiated by allowing the supersaturated solution to drain from the columns and pressurizing them to $7.03 \mathrm{~m} \mathrm{H}_{2} \mathrm{O}$ $(69 \mathrm{KPa})$. The columns that contained asphalt and synthetic liners were pressurized with oxygen, whereas the clay liner columns were pressurized with air. The pressure was maintained on the cylinders until 5 to $20 \&$ of solution were collected. Following the termination of the permeability test on a particular column, the gas pressure was vented, the volume of the collected fluid was measured, and the leachate was recycled into the reservoir above the liner. One atmosphere of oxygen pressure was maintained in the asphalt and hypalon cylinders between test cycles.

\section{LABORATORY TEST RESULTS}

The permeability values, $k$, calculated for the testing cycles are presented in Figures 4 and 5 . These values were calculated using the Darcy equation for saturated flow:

$$
k=\frac{\Delta V L}{A P t}
$$

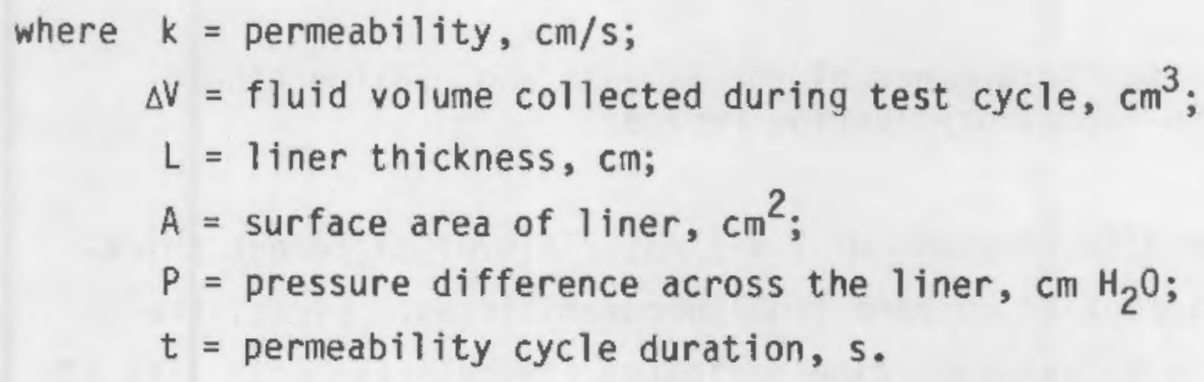

The pertinent data for each permeability test ( $\Delta V, P, t$, etc.) are listed in Appendix B. 


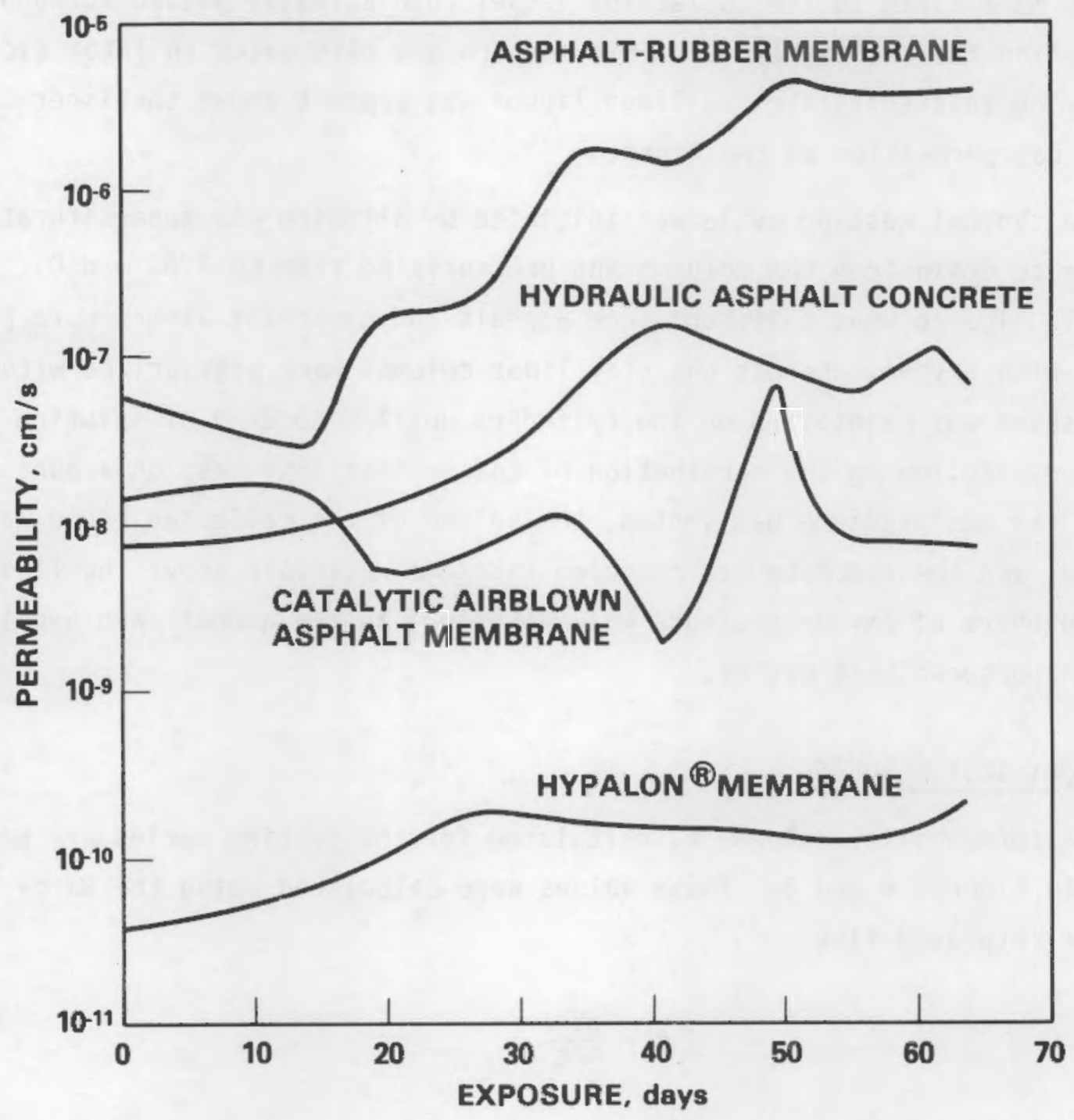

FIGURE. 4. Permeability Performance of the Asphalt and Hypalon Liners During the Laboratory Testing Period

When comparing the effectiveness of liner materials of different thicknesses, it is not sufficient to compare final permeabilities. First, the change of permeability with exposure time indicates the relative stahility of the liners. Second, a liner 10 to $20 \mathrm{~cm}$ thick in the field, such as a soil amended with bentonite, need not be as impermeable as a thin membrane to be an effective leachate barrier. Therefore, the liners were also compared by averaging the final three permeabilities and dividing by the liner field 


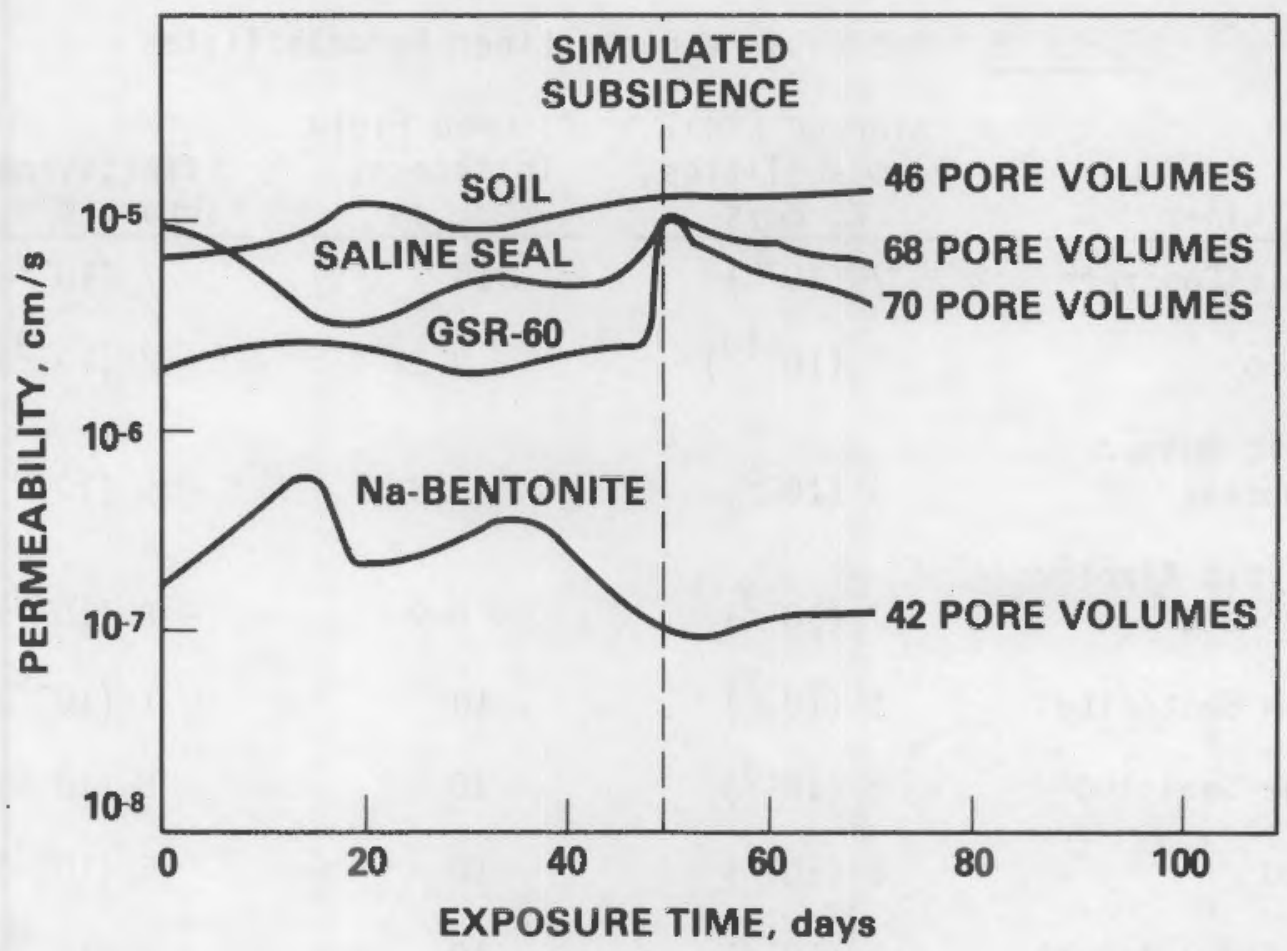

FIGURE 5. Permeability Performance of the Clay-Amended and Natural Soil Liners During the Laboratory Testing Period

thickness. The $\mathrm{K} / \mathrm{\&}$ factors, called the permeability effectiveness factors, for all the liners are listed in Table 1.

Asphalt and Synthetic Liners

With the exception of the CAA membrane, each of the asphalt and synthetic liners increased in permeability during the laboratory testing period. A discussion of the performance of each of these liners follows. The pressure, temperature and $\mathrm{pH}$ of the exposure columns during the testing period are plotted in Figures 6,7 and 8 , respectively.

\section{Asphalt-Rubber Liner}

Visual examination of the liner after the laboratory tests revealed tears in the liner at the outer edges of the exposure column. No evidence of 
TABLE 1. Anticipated Field Liner Permeabilities

\begin{tabular}{|c|c|c|c|}
\hline Liner & $\begin{array}{c}\text { Average Final } \\
\text { Permeabilities, } \\
\mathrm{K}, \mathrm{cm} / \mathrm{s} \\
\end{array}$ & $\begin{array}{c}\text { Assumed Field } \\
\text { Thickness, } \\
\ell, \mathrm{cm} \\
\end{array}$ & $\begin{array}{l}\text { Effectiveness } \\
\text { Factor, } \mathrm{K} / \ell, \mathrm{S}^{-1} \\
\end{array}$ \\
\hline Asphalt Concrete & $7\left(10^{-8}\right)$ & 10 & $7\left(10^{-9}\right)$ \\
\hline Hypalon & $2\left(10^{-10}\right)$ & 0.12 & $2\left(10^{-9}\right)$ \\
\hline $\begin{array}{l}\text { Asphalt Rubber } \\
\text { Membrane }\end{array}$ & $4\left(10^{-6}\right)$ & 0.8 & $5\left(10^{-6}\right)$ \\
\hline $\begin{array}{l}\text { Catalytic Airblown } \\
\text { Membrane }\end{array}$ & $7\left(10^{-9}\right)$ & 0.9 & $8\left(10^{-9}\right)$ \\
\hline Sodium Bentonite & $1\left(10^{-7}\right)$ & 10 & $1\left(10^{-8}\right)$ \\
\hline Saline Seal 100 & $8\left(10^{-6}\right)$ & 10 & $8\left(10^{-7}\right)$ \\
\hline GSR-60 & $6\left(10^{-6}\right)$ & 10 & $6\left(10^{-7}\right)$ \\
\hline Soil (as a liner) & $1\left(10^{-5}\right)$ & 10 & $1\left(10^{-6}\right)$ \\
\hline
\end{tabular}

failure at the repaired tear in the liner center (the liner was torn and repaired during installation) was detected. The tears along the outer edges indicate insufficient elasticity and strength during subsidence, which produced the permeability increases observed (Figure 4). A permeability increase was also observed subsequent to acid addition to the tailings leachate. This may indicate that the elastomer used in this liner is not compatible with highly acidic environments.

Hydraul ic Asphalt Concrete

The permeability of this liner increased early in the laboratory tests and then stabilized at $\sim 10^{-7} \mathrm{~cm} / \mathrm{s}$. This result suggests that one (or more) of the liner components--either the asphalt cement, the asphalt emulsion used to seal the edges, or the aggregate--was degraded by the accelerated aging testing. Comparison of the effectiveness of the liner permeability with that of other liners shows this material to be acceptable, however. 

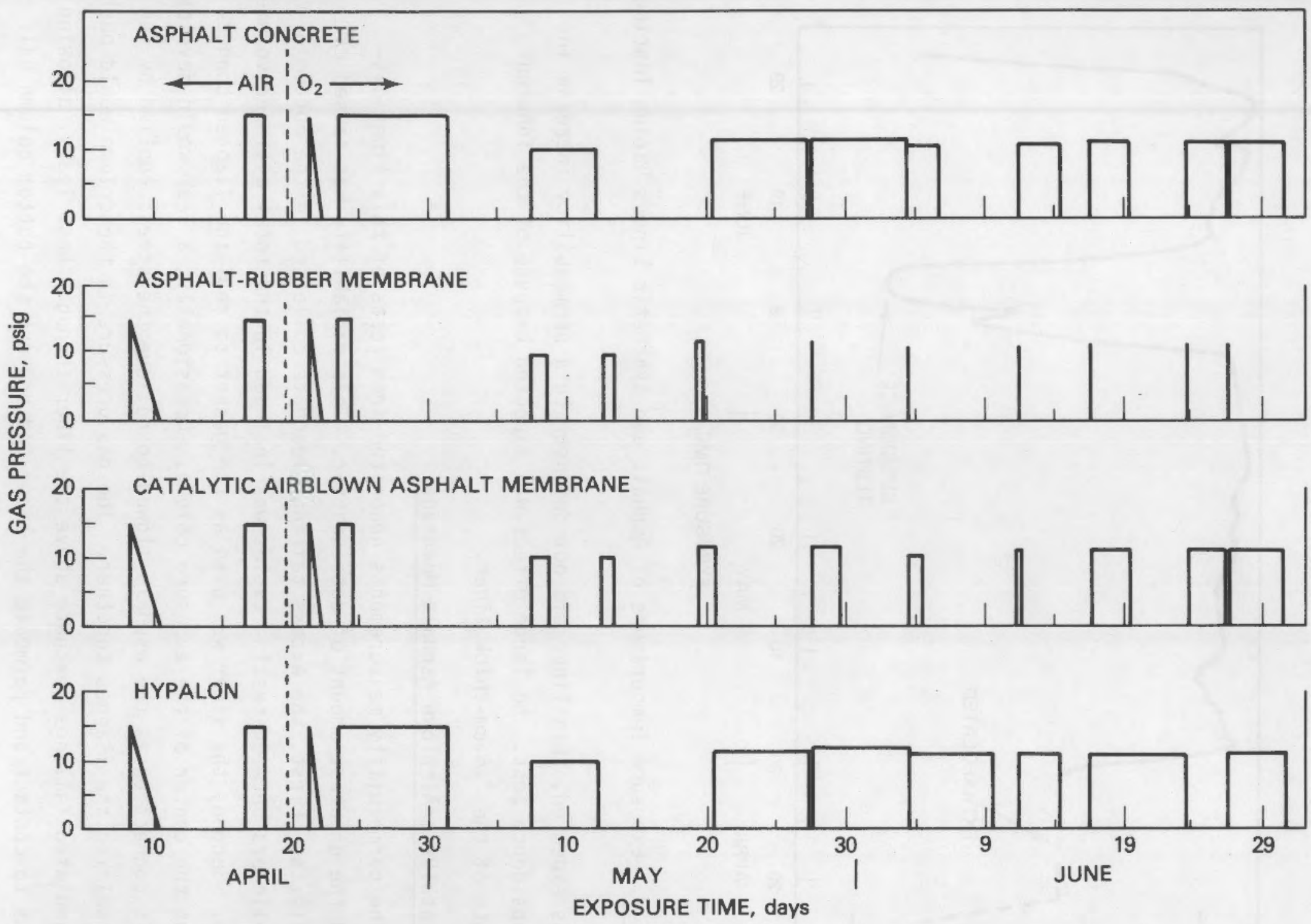

FIGURE 6. Oxygen Pressure to Which Asphalt and Synthetic Liners were Exposed During Testing 


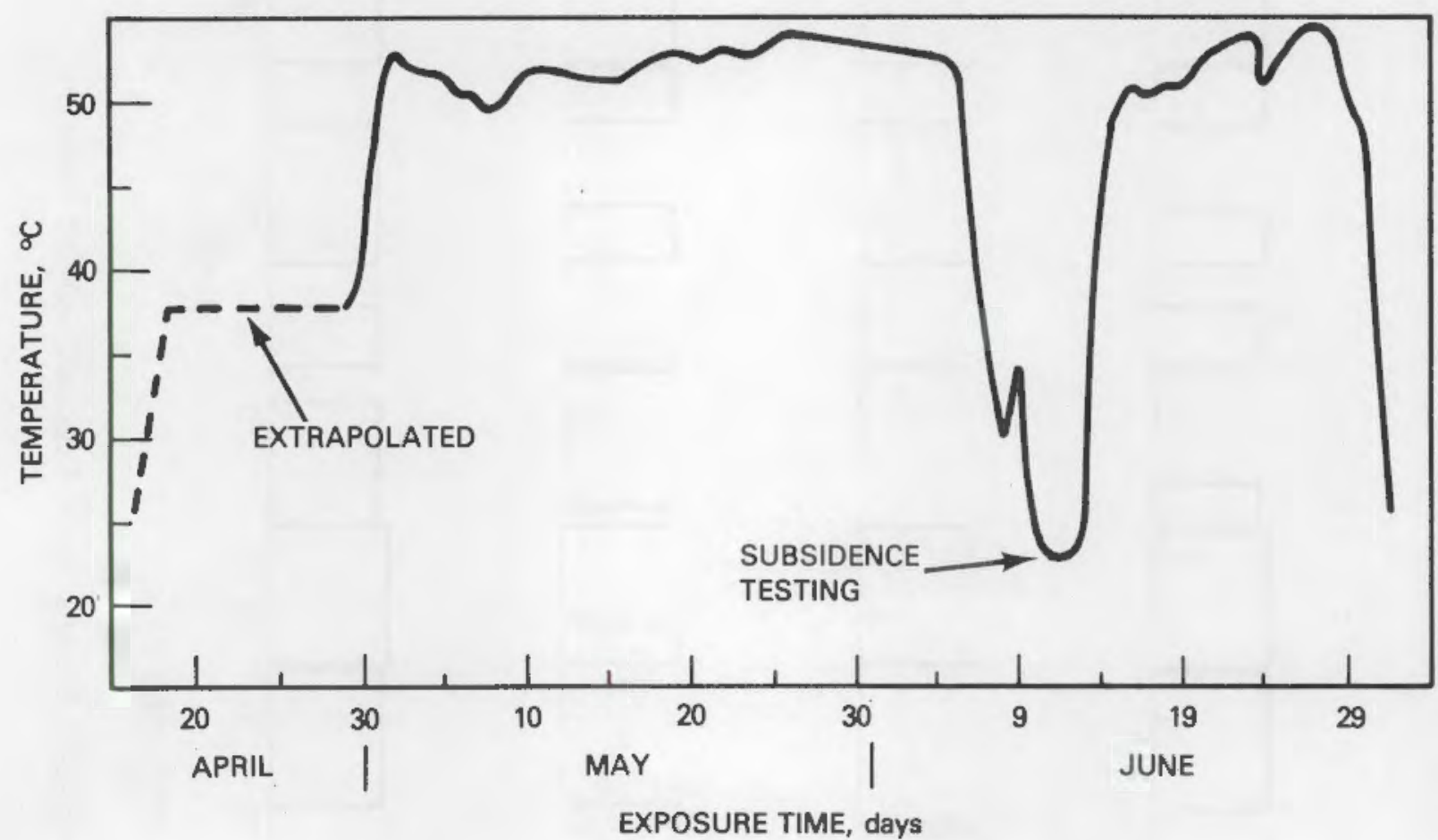

FIGURE 7. Exposure Temperature of Asphalt and Synthetic Liners During Testing

As expected, this liner did not demonstrate a permeability increase in the subsidence test. No large effect was expected because of the inherent strength of the $7.6-\mathrm{cm}-$ thick liner.

\section{Catalytic Airblown Asphalt Membrane}

The permeability measurements generated from tests of this liner displayed the greatest amount of data scatter. This variability was caused by two effects. First, the excess tailings leachate collected in the bottom of the cylinders between testing cycles was included in the total cylinder volume change. Second, the liner was used as the gasket to seal the flanged connection at the center of the exposure column. Occasionally, a leak would develop at this connection as the asphalt flowed to relieve the stress applied by the bolts holding the flanges together. The gas pressure in the column would push the simulated tailings leachate above the liner through these leaks, allowing the gas to contact and permeate the liner and dry out the bottom column half 

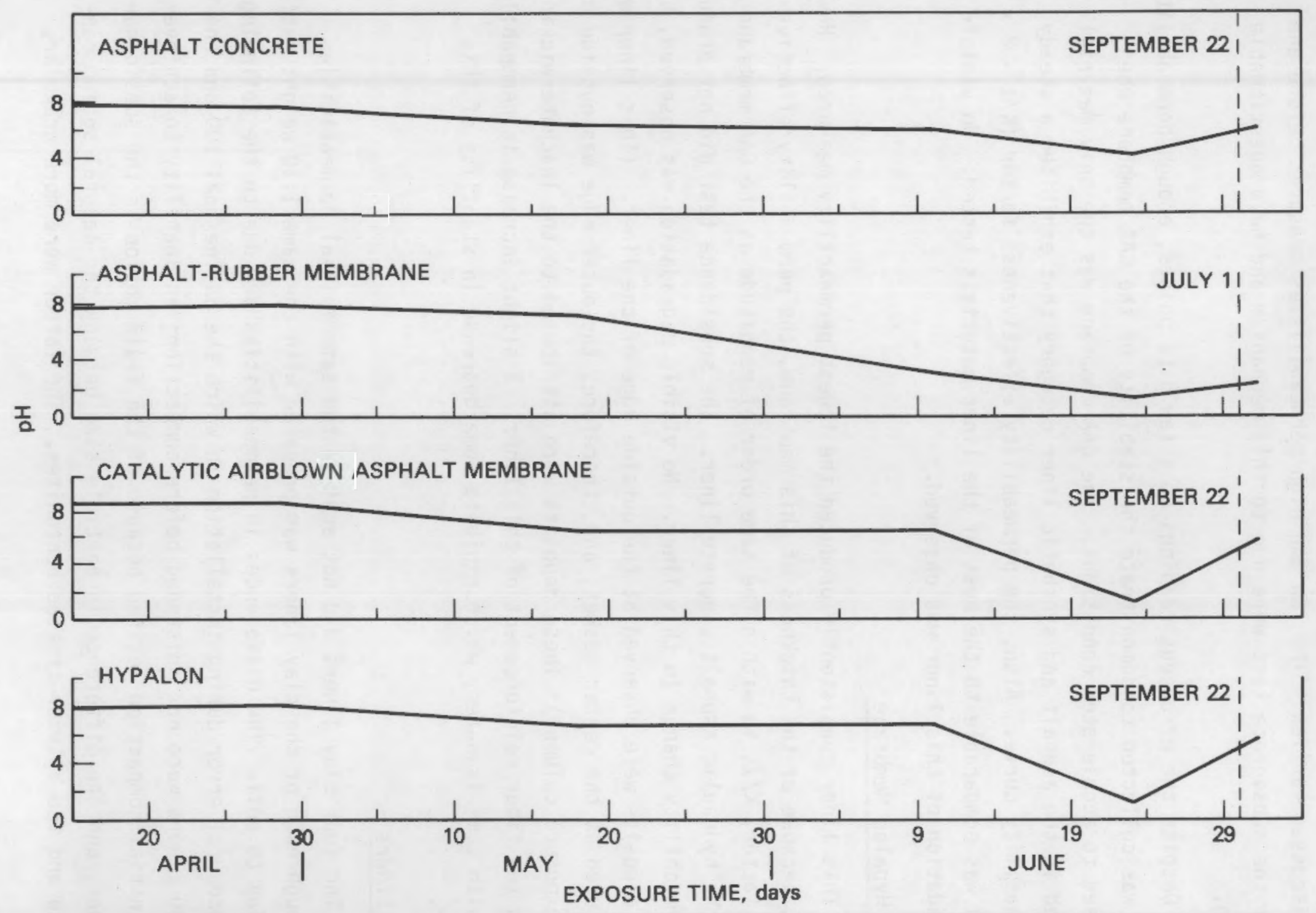

FIGURE 8. Acidity Concentration During Testing of Asphalt and Synthetic Liners (includes pH values measured after test completion, June 30 ) 
as discussed earlier. The low and high permeabilities measured before and after the subsidence test were due to this mechanism and have questionable value.

Despite the erroneous readings on a few data points, enough permeability data was collected to demonstrate the stability of the CAA membrane when exposed to accelerated conditions. The CAA membrane was the only material tested in the asphalt and synthetic liner category that exhibited a steady permeability curve. Also, the permeability effectiveness factor $(K / \ell=8 \times$ $10^{-9}$ ) was comparable to the best of the liner materials tested. No visible degradation of this liner was observed.

Hypalon Membrane

This liner consistently produced the lowest permeability measured. However, because of the thickness of this membrane, the permeability effectiveness factor, $K / \ell$, is within the same order of magnitude as the CAA membrane and the hydraulic asphalt concrete liner. The subsidence test did not produce a permeability change in this liner. No visible degradation was observed, but salt deposits were observed at the outside edge of the liner. (This liner was also used as the center gasket, and, therefore, the outer edge was outside of the exposure column.) These deposits were attributed to the leachate wicking along the fiber reinforcement of this liner. A slight increase in permeability with time is noted, which exhibits some decrease in stability of this liner.

Clay Liners

The four clay liners did not achieve the same initial permeabilities although each of the clay liners was prepared with the same 1:10 weight ratio of clay to soil. The differences in permeabilities are due to the following: a procedural error during installation in which the Saline Seal 100 and the GSR 60 liners were not moistened before compaction; an inability to achieve the initial compaction desired because of the fluid motion in the subsidence bladder; and the difference in particle size between the natural sodium bentonite and the polymer-treated bentonites. The latter were more granular, 
which inhibited the passage of the polymer-treated bentonites into the smaller pores of the soil. A thicker liner installed under field conditions should alleviate these problems.

The pressure and $\mathrm{pH}$ histories of these liners are plotted in Figures 9 and 10.

\section{Natural Soil Liner}

The natural soil liner was installed as a control to monitor any permeability change resulting from degradation of the soil. This liner displayed a generally increasing permeability trend throughout the tests.

\section{Saline Seal 100}

The Saline Seal 100 liner initial permeability was greater than that of the natural soil because of the reasons discussed earlier. The permeability of this liner decreased from the original relatively high value, reached a plateau of $\sim 6 \times 10^{-6} \mathrm{~cm} / \mathrm{s}$, and remained at this level until the subsidence test. During the subsidence test, the permeability of the liner increased as the liner was disrupted, but a slow decrease in permeability after subsidence indicates that this liner exhibits some self-healing characteristics.

$\underline{\text { GSR-60 }}$

The permeability of this liner was nearly constant $\left(3 \times 10^{-6} \mathrm{~cm} / \mathrm{s}\right)$ from the beginning of the laboratory tests until the simulated subsidence. A large permeability increase was observed during the subsidence test since this membrane was also disrupted. Again, the clay demonstrated both a tendency to seal the liner following a disruptive incident and to reduce permeability following the subsidence test.

\section{Sodium Bentonite}

The permeability of the natural sodium bentonite liner increased initially and then decreased to roughly $10^{-7} \mathrm{~cm} / \mathrm{s}$. The increase was partially the result of the early experimental variability described earlier, but also may indicate $\mathrm{Na}-\mathrm{Ca}$ ion exchange early in the laboratory test. Permeability of 

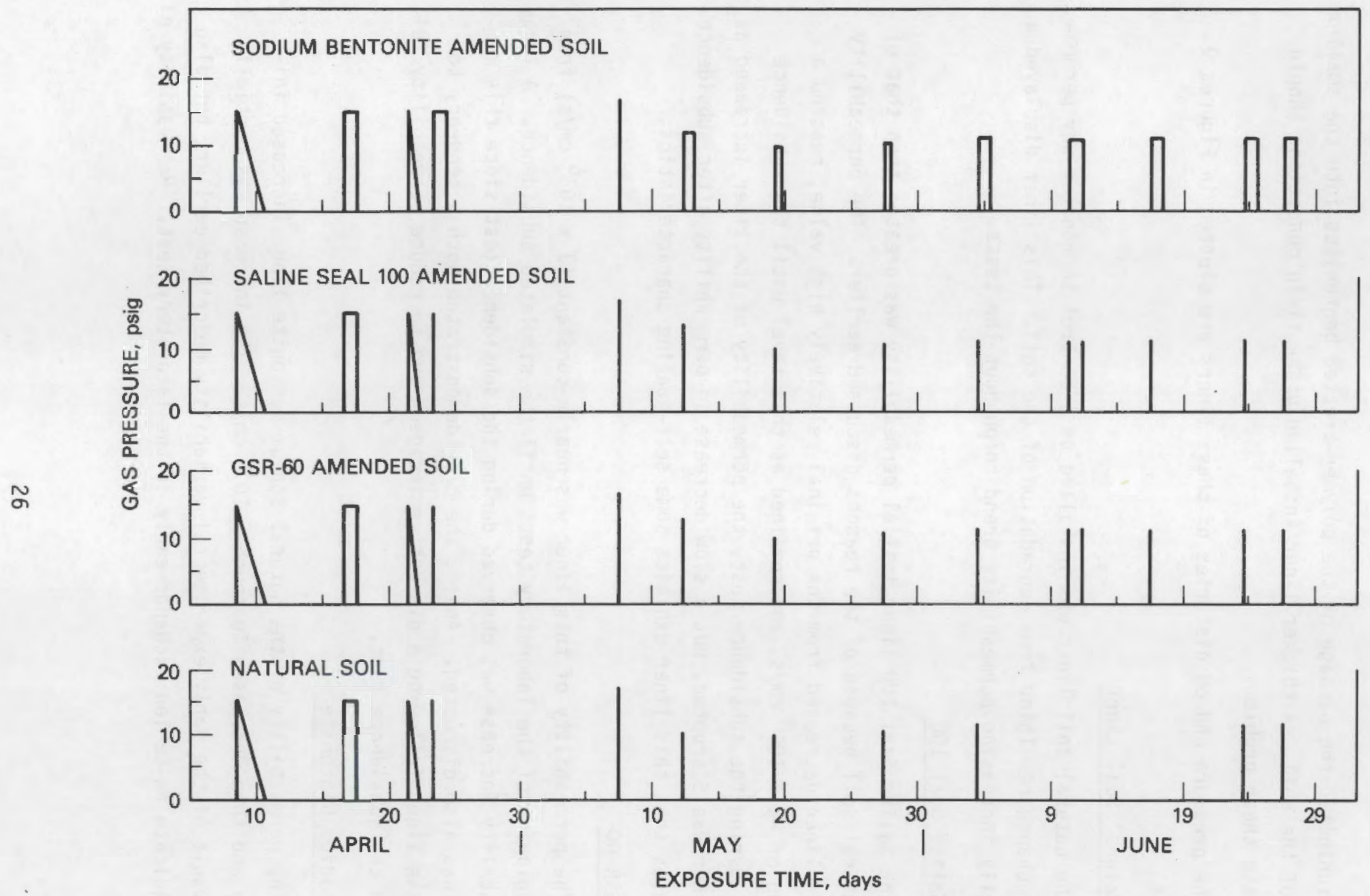

FIGURE 9. Pressure History During Testing of $\mathrm{Cl}$ ay Liners 

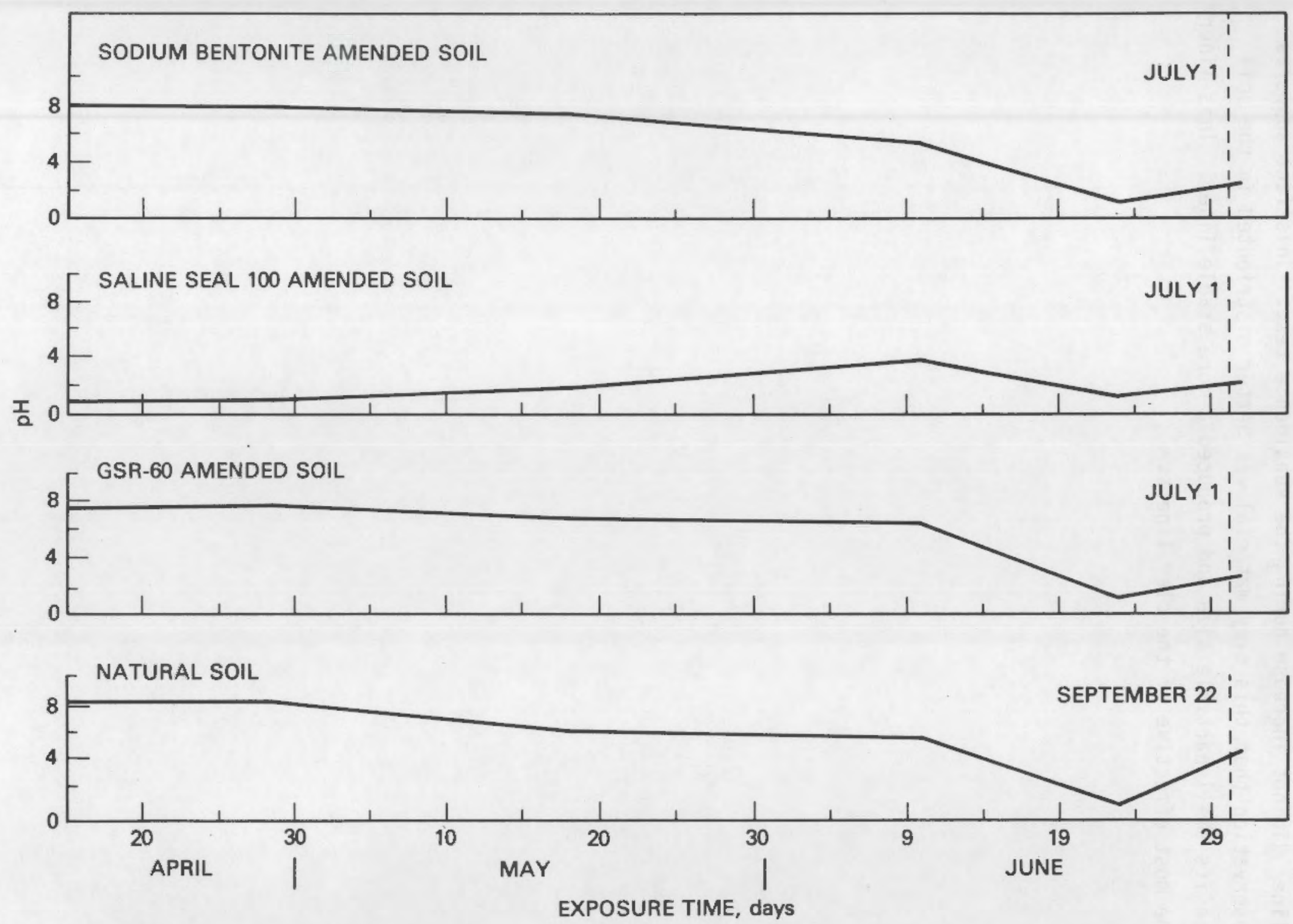

FIGURE 10. Acidity Concentration During Testing of $\mathrm{Clay}$ Liners (includes pH values measured after test completion, June 30 ) 
this liner did not increase during the subsidence test. This fact supports the observation that this clay material was better distributed in the soil because its small particle size and produced a more stable liner. This liner was the most effective of the clay liners. 


\section{$\underline{\text { LINER INSTALLATION COSTS }}$}

The installation costs of the various liners were estimated by contacting the vendors of the liners and the installation contractors. Each was asked to provide pricing information based on a 200,000- $m^{2}$ impoundment in Grand Junction, Colorado. The installed costs are presented in Table 2.

IABLE 2. Installation Costs of the Candidate Liner Materials

\begin{tabular}{|c|c|c|}
\hline Liner & Installation Rate & Installed Cos \\
\hline Asphalt concrete & $\begin{array}{l}\text { Two } 5 \text {-cm lifts with cationic } \\
\text { asphalt }{ }_{2} \text { emulsion tack coat } \\
\left(\sim 3 / / \mathrm{m}^{2}\right)\end{array}$ & $\$ 9.60 / \mathrm{m}^{2(a)}$ \\
\hline Hypal on & $0.9 \mathrm{~mm}$ & $\$ 7.80 / \mathrm{m}^{2}(\mathrm{a}, \mathrm{b})$ \\
\hline Asphalt-rubber & $5.4 \mathrm{l} / \mathrm{m}^{2}$ & $\$ 4.40 / m^{2}(a, b)$ \\
\hline Catalytic airblown asphalt & $6.8 \mathrm{l} / \mathrm{m}^{2}$ & $\$ 4.30 / m^{2}(a, b)$ \\
\hline Saline Seal 100 & $20 \mathrm{~kg} / \mathrm{m}^{2}$ & $\$ 4.70 / \mathrm{m}^{2}(\mathrm{c})$ \\
\hline GSR-60 & $20 \mathrm{~kg} / \mathrm{m}^{2}$ & $\$ 2.70 / \mathrm{m}^{2}(\mathrm{c})$ \\
\hline Sodium bentonite & $20 \mathrm{~kg} / \mathrm{m}^{2}$ & $\$ 2.30 / m^{2}(c)$ \\
\hline
\end{tabular}

(a) Assumes $3-i n$. (7.6-cm) soil installed beneath liner $0 \$ 5.20 / \mathrm{m}^{3}$

(b) Assumes $12-\mathrm{in} .(30.5-\mathrm{cm})$ soil installed above liner $0 \$ 5.20 / \mathrm{m}^{3}$

(c) Assumes that 4-in. (10.2-cm) layer of clay and soil installed with soi] a $\$ 5.20 / \pi^{3}$ 


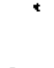




\section{CONCLUS IONS}

The findings of accelerated liner testing include:

- Expected y-irradiation in the field will not impair the liner performance over the 1000-yr period.

- Simulated subsidence indicated that the asphalt concrete, hypalon, sodium bentonite-amended soil, and probably the catalytic airblown membrane will give the best performance.

- The liners with the best expected field performance, as determined by permeability effectiveness factors, $K / \ell$, are hydraulic asphalt concrete, catalytic airblown asphalt, hypalon and sodium-bentonite amended soil.

- The most stable of the liners tested, as determined by the change of permeability with time, are catalytic airblown asphalt and soil amended with natural sodium bentonite.

- The initial permeability increase measured on the soil and natural sodium bentonite liners may indicate that rapid $\mathrm{Na}-\mathrm{Ca}$ ion exchange is occurring. However, since the overall performance was not affected, we can assume that the resulting shrinkage must occur vertically. This needs to be confirmed by determining the extent of the ion-exchange reaction and the direction of shrinkage.

- The least-expensive of the asphalt and synthetic materials to install are asphalt-rubber and catalytic airblown asphalt. The least expensive of the clay materials to install are natural sodium bentonite and GSR-60.

Based on the laboratory testing results, expected field effectiveness and the cost analysis, the liners selected for the fiscal year 1981 field studies are catalytic airblown asphalt and sodium bentonite-amended soil. 



\section{REFERENCES}

Blokker, P. C. and H. van Hoorn. 1959. Durability of Bitumen in Theory and Practices. Fifth World Petroleum Congress, New York, New York.

Buelt, J. L., V. Q. Hale, S. M. Barnes and D. J. Silviera. 1981. An Evaluation of Liners for a Uranium Mill Tailings Disposal Site--A Status Report. PNL-3679, DOE/UMT-0200, Pacific Northwest Laboratory, Richland, Washington.

Environmental Protection Agency (EPA). 1981. Proposed Disposal Standards for Inactive Uranium Processing Sites. 40 CFR Part 192, Federal Register, Vol. 46 , No. 6.

Foster, A. R. and R. L. Wright, Jr. 1973. Basic Nuclear Engineering. Allyn and Bacon, Inc., Boston, Massachusetts.

Hartley, J. N., et al. 198D. Annual Report on the Asphalt Emulsion Sealing of Uranium Mill Tailings. PNL-3752, DOE/UMT-0201, Pacific Northwest Laboratory, Richland, Washington.

Hillel, Daniel. 1980. Fundamentals of Soil Physics. Academic Press, Inc., New York, New York.

van Dort, H. P. 1956. Durability of Asphalt--Its Aging in the Dark. Kowinklyke-Shell Laboratorium, Amsterdam, The Netherlands. 

APPENDIX A

ASPHALT LINER SPECIF ICATIONS 


\section{ASPHALT LINER SPECIFICATIONS}

TABLE A.1. AR4000 Asphalt Cement Specifications

\begin{tabular}{|c|c|c|c|}
\hline Property & Minimum & Maximum & Actual \\
\hline \multicolumn{4}{|l|}{ Tests on original asphalt } \\
\hline - Flash point, P-M, ${ }^{\circ} \mathrm{F}$ & 440 & & 480 \\
\hline - Solubility in trichloroethylene, $\%$ & 99 & & 99.9 \\
\hline \multicolumn{4}{|l|}{ Tests on residue from RTFC } \\
\hline - Absolute viscosity $140^{\circ} \mathrm{F}$, ps & 2500 & 5000 & 3260 \\
\hline - Kinematic viscosity a $275^{\circ} \mathrm{F}, \mathrm{cs}$ & 275 & & 414.6 \\
\hline - Penetration $77^{\circ} \mathrm{F}, 100 \mathrm{~g} / 5 \mathrm{~s}$ & 40 & & 53 \\
\hline - Percent of original penetration $\left(77^{\circ} \mathrm{F}\right.$ & 45 & & 51 \\
\hline - Ductility $\left(\mathrm{a} 45^{\circ} \mathrm{F},(1 \mathrm{~cm} / \mathrm{min}) \mathrm{cm}\right.$ & 10 & & $50+$ \\
\hline
\end{tabular}

TABLE A.2. Hydraulic Asphalt Concrete Aggregate Specifications

\begin{tabular}{|c|c|}
\hline Grid Size & $\$$ Passing \\
\hline $1 / 2$ & 100 \\
\hline $3 / 8$ & 100 \\
\hline 4 & 77 \\
\hline 8 & 60 \\
\hline 10 & 54 \\
\hline 30 & 44 \\
\hline 50 & 23 \\
\hline 100 & 17 \\
\hline 200 & 15 \\
\hline
\end{tabular}


TABLE A.3. Catalytic Airblown Asphalt Specifications

\begin{tabular}{|c|c|c|}
\hline Property & ASTM Specifications & Actua 1 \\
\hline Softening Point & $\begin{array}{l}82^{\circ} \mathrm{C} \text { to } 93^{\circ} \mathrm{C} \\
\left(180 \text { to } 200^{\circ} \mathrm{C}\right)\end{array}$ & $85^{\circ} \mathrm{C}$ \\
\hline Penetration $25^{\circ} \mathrm{C}$ & 50 to 60 (min./max.) & 53 \\
\hline Ductility & $3.5 \mathrm{~cm} / \mathrm{min} 25^{\circ} \mathrm{C}$ & $3.75 \mathrm{~cm}$ \\
\hline Penetration $\theta 0^{\circ} \mathrm{C}$ & $30 \mathrm{~min}$. & 32 \\
\hline Flash Point & $230^{\circ} \mathrm{C}$ & $\sim 290^{\circ} \mathrm{C}$ \\
\hline Specific Gravity & $1.00 \mathrm{~min}$. & $\sim 1.01$ \\
\hline
\end{tabular}


APPENDIX B

PERMEAB IL ITY TEST DATA 
TABLE B.1. Laboratory Permeability Testing Oata

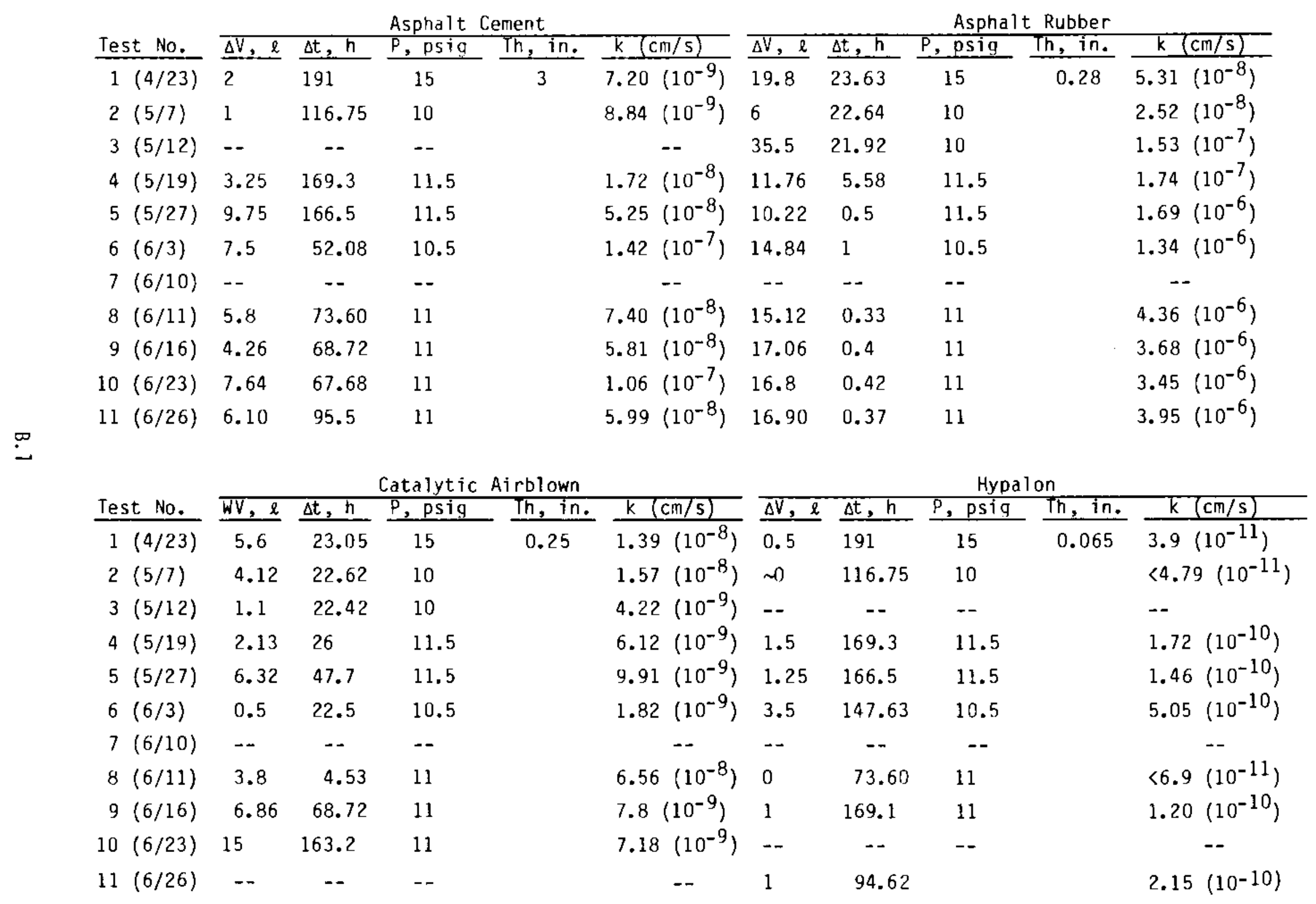


TABLE B.1. (Contd)

\begin{tabular}{|c|c|c|c|c|c|c|c|c|c|c|}
\hline \multirow[b]{2}{*}{ est No. } & \multicolumn{5}{|c|}{ Bentonite } & \multicolumn{5}{|c|}{ Saline Seal 100} \\
\hline & $\overline{\Delta V, \ell}$ & $\Delta t, h$ & $p, p s i g$ & Th, in. & $\mathrm{k}(\mathrm{cm} / \mathrm{s})$ & $\overline{\Delta V, \ell}$ & $\Delta t, h$ & p,psig & Th, in. & $k(\mathrm{~cm} / \mathrm{s})$ \\
\hline \multirow{12}{*}{$\begin{array}{ll}1 & (4 / 23) \\
2 & (5 / 7) \\
3 & (5 / 12) \\
4 & (5 / 19) \\
5 & (5 / 27) \\
6 & (6 / 3) \\
7 & (6 / 10) \\
8 & (6 / 11) \\
9 & (6 / 16) \\
0 & (6 / 23) \\
1 & (6 / 26)\end{array}$} & $\overline{18.8}$ & 23.05 & 15 & 1 & $1.87\left(10^{-7}\right)$ & $\overline{9.7}$ & 0.5 & 15 & 1 & $9.08\left(10^{-6}\right)$ \\
\hline & 4.96 & 1.65 & 15 & & $6.89\left(10^{-7}\right)$ & 18.5 & 1 & 17 & & $3.74\left(10^{-6}\right)$ \\
\hline & 18.1 & 21.92 & 12 & & $2.37\left(10^{-7}\right)$ & 11.2 & 0.5 & 13.3 & & $5.79\left(10^{-6}\right)$ \\
\hline & 4.62 & 5.58 & 10 & & $2.85\left(10^{-7}\right)$ & 13.8 & 0.75 & 10 & & $6.33\left(10^{-6}\right)$ \\
\hline & 5.24 & 3.88 & 10.5 & & $4.42\left(10^{-7}\right)$ & 15.1 & 1 & 10.5 & & $4.94\left(10^{-6}\right)$ \\
\hline & 13.3 & 22.5 & 11 & & $1.85\left(10^{-7}\right)$ & 16.6 & 1 & 11. & & $4.71\left(10^{-6}\right)$ \\
\hline & 6.56 & 23 & 11 & & $8.92\left(10^{-8}\right)$ & 16.83 & 0.92 & 11 & & $5.72\left(10^{-6}\right)$ \\
\hline & 6.62 & 23.17 & 11 & & $8.93\left(10^{-8}\right)$ & 15.94 & 0.58 & 11 & & $8.59\left(10^{-6}\right)$ \\
\hline & 8.72 & 23 & 11 & & $1.19\left(10^{-7}\right)$ & $16.68^{\circ}$ & 0.62 & 11 & & $8.46\left(10^{-6}\right)$ \\
\hline & 11.88 & 24 & 11 & & $1.55\left(10^{-7}\right)$ & 16.32 & 0.63 & 11 & & $8.10\left(10^{-6}\right)$ \\
\hline & 10.81 & 20.75 & 11 & & $1.63\left(10^{-7}\right)$ & 10.54 & 0.5 & 11 & & $6.59\left(10^{-6}\right)$ \\
\hline & \multicolumn{5}{|c|}{ GSR -60} & \multicolumn{5}{|c|}{ Soil } \\
\hline Test No. & $\Delta V, l$ & $\Delta t, h$ & $\overline{p, p s i g}$ & Th, in. & $k(\mathrm{~cm} / \mathrm{s})$ & $\Delta V, \ell$ & $\Delta t, h$ & $p, p$ sig & Th, in. & $\mathrm{k}(\mathrm{cm} / \mathrm{s})$ \\
\hline $1(4 / 23)$ & 19.3 & 2.42 & 15 & 1 & $1.83\left(10^{-6}\right)$ & 15.8 & 0.5 & 15 & 1 & $7.24\left(10^{-6}\right)$ \\
\hline $2(5 / 7)$ & 15.26 & 1 & 17 & & $3.09\left(10^{-6}\right)$ & 14 & 0.37 & 17 & & $7.65\left(10^{-6}\right)$ \\
\hline $3(5 / 12)$ & 7.7 & 1 & 12.5 & & $2.12\left(10^{-6}\right)$ & 14.5 & 0.42 & 10 & & $1.19\left(10^{-5}\right)$ \\
\hline $4(5 / 19)$ & 14.75 & 2.75 & 10 & & $1.84\left(10^{-6}\right)$ & 12.0 & 0.5 & 10 & & $8.25\left(10^{-6}\right)$ \\
\hline $5(5 / 27)$ & 16.22 & 2 & 10.5 & & $2.66\left(10^{-6}\right)$ & 16.18 & 0.5 & 10.5 & & $1.06\left(10^{-5}\right)$ \\
\hline $6(6 / 3)$ & 15.8 & 1.5 & 11 & & $3.16\left(10^{-6}\right)$ & 18.25 & 0.5 & 11.0 & & $1.14\left(10^{-5}\right)$ \\
\hline $7(6 / 10)$ & 16.86 & 1.5 & 11 & & $3.51\left(10^{-6}\right)$ & - & -- & -- & & -- \\
\hline $8(6 / 11)$ & 16.44 & 0.66 & 11 & & $7.79\left(10^{-6}\right)$ & -- & -- & -- & & -- \\
\hline $9(6 / 16)$ & 16.24 & 0.78 & 11 & & $6.48\left(10^{-6}\right)$ & -- & -- & -- & & -- \\
\hline $10(6 / 23)$ & 16.42 & 0.9 & 11 & & $5.70\left(10^{-6}\right)$ & 16.12 & 0.42 & 11 & & $1.20\left(10^{-5}\right)$ \\
\hline $11(6 / 26)$ & 7.5 & 0.5 & 11 & & $4.69\left(10^{-6}\right)$ & 16.64 & 0.47 & 11 & & $1.11\left(10^{-5}\right)$ \\
\hline
\end{tabular}


No. of

Copies

OFFSITE

A. A. Churm

DOE Chicago Patent Group

9800 South Cass Avenue

Argonne, IL 60439

27 DOE Technical In formation Center

G. Birchard

Majl Station 1130-SS

Nuclear Regulatory Commission

Washington, DC 20555

R. E. Cunningham

Office of Nuclear Safety, Materials and Safeguards Room 562

Nuclear Regulatory Commission 7915 Eastern Avenue

Silver Springs, MD 20910

W. Nixon

Office of Nuclear Materials, Safety and Safeguards

Majl Station 396-SS

Nuclear Regulatory Commission

Washington, DC 20555

Waste Management Research Branch

Division of Safeguards

Fuel Cycle and Environmental Research

Nuclear Regulatory Commission

Washington, DC 20545

P. E. Leader

New Uranium Mill Licensing Section

Nuclear Regulatory Commission

Washington, DC 20545
No. of

Copies

H. J. Miller

New Uranium Mill Licensing

Section

Nuclear Regulatory Commission

Washington, DC 20545

R. A. Scarano, Chief

Uranium Recovery License Branch

Mail Station 483-SS

Nuclear Regulatory Commission

Washington, DC 20555

W. E. Mott

DOE Division of Environmental Control Technology

Washington, DC 20545

K. Baker

Remedial Actions Program

Office of Nuclear Waste

Management

Department of Energy

NE-301, GTN

Washington, DC 20545

E. De laney

Remedial Actions Program

Office of Nuclear Waste

Management

Department of Energy

NE-301, GTN

Washington, DC 20545

D. H. Gorel serna

Remedial Actions Program

Office of Nuclear Waste

Management

Department of Energy

NE-301, GTN

Washington, DC 20545 
No. of

Copies

A. Kluk

Remedial Actions Program

Office of Nuclear Waste

Management

Department of Energy

NE-301, GTN

Washington, DC 20545

R. W. Ramsey, Jr. Program Manager

Remedia! Actions Program

Department of Energy

NE-301, GTN

Washington, DC 20545

S. Meyers

Office of Nuclear Waste

Management

Department of Energy

NE-30, GTN

Washington, OC 20545

G. Oertel

Office of Nuclear Waste

Management

Department of Energy

$\mathrm{NE}-320$, GTN

Washington, DC 20545

S. A. Mann

DoE Chicago Operations and Region Office

Argonne, IL 60439

J. 0 . Neff

DOE Colurnbus Program Office $505 \mathrm{King}$ Avenue

Columbus, $\mathrm{OH} 43201$

J. P. Hamric

DOE Idaho Operations Office

$505 \mathrm{King}$ Avenue

Idaho Falls, ID 83401
No. of

Copies

2 J. B. Whitsett

DOE Idaho Operations Office

$505 \mathrm{King}$ Avenue

Idaho Falls, ID 83401

S. W. Ahrends

DOE Oak Ridge Operations Office P.0. Box E

Oak Ridge, TN 37380

E. L. Keller

DOE Oak Ridge Operations Office P.0. Box E

Oak Ridge, IN 37380

0. E. Large

DOE Oak Ridge Operations Office P.0. Box E

Oak Ridge, TN 37380

T. B. Hindman

DOE Savannah River Operations Office

P.0. Box A

Aiken, SC 29801

R. P. Whitfieid

DOE Savannah River Operations Office

P.0. Box A

Aiken, SC 29801

W. B. Wilson

DOE Savannah River Operations Office

P.0. Box A

Aiken, SC 29801

R. H. Campbell

DOE Albuquerque Operations

Office

P.0. Box 5400

Albuquerque, NM 87185 
No. of

Copies

R. Y. Lowrey

DOE Albuquerque Operations office

P. 0. Box 5400

Albuquerque, NM 87185

M. L. Matthews

DOE Albuquerque Operations Office

P.0. Box 5400

Albuquerque, NM 87185

A. L. Taboas

OOE Albuquerque Operations Office

P.0. Box 5400

Al buquerque, NM 87185

S. G. Harbinson

DUE San Francisco Operations Office

1333 Broadway

Oakland, CA 94612

S. Lichtman

Criteria \& Standards Oivision

Office of Radiation Programs

Environmental Protection Agency

Washington, DC 20460

Environmental Protection Agency

Technological Assessment Division

(AN-559)

Office of Radiation Programs

Washington, DC 20460

J. G. Themelis, Director

Engineering \& Safety Division

DOE Grand Junction Office

P.0. Box 2567

Grand Junction, C0 81501
No. of

Copies

Robert Williams

Electric Power Research

Institute

3412 Hillview Avenue

Palo Alto, CA 94304

4 T. Gerusky, Director

Bureau of Radiation Protection

P.0. Box 2063

Harrisburg, PA 17120

4 Edgar 0. Bailey

P. E., Administrator

Radiation Control Branch

Texas Department of Health

1100 West 49th Street

Austin, TX 78756

4 A. J. Hazle, Director

Radiation \& Hazardous Wastes Oivision

Colorado Department of Health

4210 East 11th Avenue

Denver, C0 80220

4 Ted Wolfe, Environmental Manager

Radiation Department

P. 0 . Box 968

Santa Fe, NM 87503

4 Lynn Frank, Director

Oregon Department of Energy

111 Labor \& Industries Building

Salem, OR 97310

4 Dana $K$. Mount

P. E., Director

Division of Environmental Engr.

North Dakota State Department of Health

1200 Missouri Avenue

Roorn 304

Bismark, ND 58505 
No. of

Copies

4 Robert Funderberg

Department of Health \& Welfare Statehouse

Boise, ID 83707

4 Harold Tso, Executive Director

Environmental Protection Commission

Navajo Tribe

Window Rock, AZ 86515

4 John W. Mckiernan

Organization 4542

Sandia National Laboratory

P.0. Box 5800

Albuquerque, NM 87185

P. O'Brien, Organization 4541

Sandia National LaboratoryA1 buquerque

P. 0. Box 5800

Albuquerque, NM 87185

Dr. Gergely Markos, Manager

Uranium Research Program

South Dakota School of Mines and Technology

Rapid City, SD 57701

Vern C. Rogers

P. E., President

Rogers \& Associates Engineering

445 East 200 South

Suite 303

Salt Lake City, UT 84111

4 Larry Anderson, Director

Bureau of Radiation \&

Occupational Health

P. 0. Box 2500

Salt Lake City, UT 84110
No. of

Copies

4 Walt Ackerman, Di rector

Department of Environmental

Quality

Land Quality Division

Hathaway Building

Cheyenee, WY 82002

Lynn Fitzronodolph

Arizona Atomic Energy Commission

2929 West Indian School Road

Phoenix, AZ 85017

Robert Overmyer

Ford, Bacon \& Davis-Utah

P.0. Box 8009

Salt Lake City, UT 84108

W. Chappell

University of Colorado-Denver

P.0. Box 136

Denver, C0 80202

T. N. Narasimhan

Lawrence Berkeley Laboratory

Berkeley, CA 94720

D. Dressen

Los Al amos Scientific Laboratory

P.0. Box 1663

Los Al amos, NM 87545

W. Kislieski

Argonne National Laboratory

9700 South Cass Avenue

Argonne, IL 60439

Dr. John D. Nelson

Colorado State University

Ft. Collins, CO 80523

R. Kennedy

Ford, Bacon \& Davis-Utah

Utah Operations

2009 N. 14th Street

Suite 603

Arlington, VA 20009 
No. of

Copies

$R$. Neff

Mound Facility

c/o Dayton Area Office

P.0. Box 66

Miamisburg, $\mathrm{OH} 45342$

F. Haywood

Oak Ridge National Laboratory

P.0. Box $X$

Oak Ridge, TN 37380

A. Ryon

Oak Ridge National Laboratory

P. 0. Box $X$

Oak Ridge, TN 37830

W. Staub

Dak Ridge National Laboratory

P.0. Box $X$

0ak Ridge, TN 37830

T. Tamura

Oak Ridge National Laboratory P.0. Box X

Oak Ridge, TN 37830

J. Morse

Colorado Energy Research Institute

2221 East Street

Golden, C0 80401

K. R. Porter

Dames \& Moore

1626 Cole Blvd.

Golden, CO 80401

R. Ol son

Civil Engineering Department

University of Texas

Crockrell Hall

Austin, TX 78712

George Stukenbroeker

NLO, Inc.

P.0. Box 39158

Cincinnati, $\mathrm{OH} \quad 45239$
No. of

Copies

A1 Askew

Politech Corporation

2220 Austin National Bank Tower

Austin, TX 78701

J. N. Dybalski

Armak Company

8401 West 47 th Street

McCook, IL 60525

D. Phoenix

Weston

Weston Way

West Chester, PA 19380

ONS ITE

3 DOE Richland Operations Office

P. A. Craig

H. E. Ransom

J. D. White

4 Rockwell Hanford 0perations

J. L. Deichman (3)

J. H. Roecker

UNC United Nuclear Industries

F. H. Bouse

Westinghouse Hanford Company

A. G. Blasewitz

50 Pacific Northwest Laboratory

S. M. Barnes (5)

P. A. Beedlow

W. F. Bonner

J. L. Buelt (10)

L. L. Cadwell

T. D. Chikalla

J. F. Cline

M. R. Elmore 
No. of

Copies

Pacific Northwest Laboratory

(contd)

D. J. Esterl

H. D. Freeman

G. W. Gee

V. Q. Hale

J. N. Hartley

P. L. Koehmstedt

J. M. Latkovich

G. B. Long (3)

J. L. McEl roy

M. C. McShane

D. A. Nelson

R. W. Nelson

B. Opitz

A. M. Platt

D. Sherwood

D. J. Silviera

P. C. Walkup/R. E. Nightingale

R. A. Walter/D. B. Cearlock

M. L. Warner/B. E. Vaughan

J. Zellmer

Technical Information (5)

Publishing Coordination EI (2) 